TEME, г. XLII, бр. 4, октобар - децембар 2018, стр. 1237-1251

Претходно саопштење

DOI: $10.22190 /$ TEME1804237A

Примљено: 11. 6. 2017.

UDK 330.322.1(4-12)

Ревидирана верзија: 27. 12. 2017.

Одобрено за штампу: 12. 6. 2018.

\title{
IMPACT OF MACROECONOMIC FACTORS ON \\ FOREIGN DIRECT INVESTMENT IN SELECTED SOUTHEASTERN EUROPEAN COUNTRIES
}

\author{
Jelena Andrašić, Vera Mirović, Branimir Kalaš" \\ University of Novi Sad, Faculty of Economics in Subotica, Subotica, Serbia \\ *branimir.kalas@ef.uns.ac.rs
}

\begin{abstract}
Foreign direct investment has a significant role in Southeastern European countries. The aim of the paper is reflected in assessing the character and nature of the relationship between macroeconomic factors and foreign direct investment in Southeastern European countries. Further, the subject of paper includes the examination of the impact of selected macroeconomic variables on foreign direct investment in six countries for the period from 2000 to 2012. The selected countries are Albania, Bosnia and Herzegovina, Bulgaria, Macedonia, Romania and Serbia. The research includes an examination impact of market size, national competitiveness and employment on foreign direct investment. By using the Hausman test, it was confirmed that the fixed effect model is an appropriate model in panel analysis. Based on the result, it determined the positive impact of market size, while the industry's share of GDP and employment have a negative impact on this variable. Also, the results confirmed that only the market size of the countries significantly affected on the flow of foreign direct investment in Southeastern European countries.
\end{abstract}

Key words: foreign direct investment, macroeconomic factors, Southeastern European countries.

\section{УТИЦАЈ МАКРОЕКОНОМСКИХ ФАКТОРА НА СТРАНЕ ДИРЕКТНЕ ИНВЕСТИЦИЈЕ У ОДАБРАНИМ ЗЕМЉАМА ЈУГОИСТОЧНЕ ЕВРОПЕ}

\section{Апстракт}

Стране директне инвестиције имају значајну улогу у земљама југоисточне Европе. Циљ рада огледа се у оцењивању карактера и природе односа између макроекономских фактора и страних директних инвестиција у земљама југоисточне Европе. Даље, предмет рада обухвата сагледавање утицаја одабраних макроекономских варијабли на стране директне инвестиције у шест земаља за период од 2000. до 2012. године. Посматране земље су Албанија, Босна и Херцеговина, Бугарска, Македонија, Румунија и Србија. Истраживање укључује испитивање утицаја величине тржишта, националне конкурентности и запослености на 
стране директне инвестиције. Коришћењем Хаусман теста потврђено је да тзв. рандом ефект модел представља адекватан модел у панел-анализи. На основу резултата, утврђен је позитиван утицај величине тржишта, док учешће индустрије у БДП-у и запосленост имају негативан утицај на ову варијаблу. Такође, резултати су потврдили да само величина тржишта значајно утиче на прилив страних директних инвестиција у земљама југоисточне Европе.

Кључне речи: стране директне инвестиције, макроекономски фактори, земље југоисточне Европе.

\section{INTRODUCTION}

One of the fundamental characteristics of contemporary world economy is the globalization and liberalization process where foreign direct investment has greater role in the world, especially in Southeastern European countries. Namely, foreign capital is an important part of their economic flows and a necessary condition for the faster development of national economies.

In the past decade, transition economies were the biggest receivers of foreign direct investment, which were primarily driven by low costs of the workforce, market liberalization and natural resources. In Southeastern European countries, foreign direct investment mostly came in form of privatization of domestic companies by foreign investors from the European Union countries.

Liberalization of the market of Southeastern European countries has started in 2001 with the signing of Memorandum on Trade Liberalization and Facilitation of Trade in Brussels, under The Stability Pact for Southeastern European countries. In this way, process of negotiations is opened which led to concluding a network of 32 agreements on mutual liberalization of trade of industrial and agricultural products that has been established between the countries of Central and Southeastern Europe, respectively Albania, Bosnia and Herzegovina, Bulgaria, Croatia, Macedonia, Moldova, Romania, Serbia and Montenegro (Agency for Foreign Investments and Export Promotion, 2015).

Looking at the countries in the region, the biggest receivers of total foreign direct investment in the period leading up to the onset of the economic and financial crisis were three countries EU members: Bulgaria, Romania and Croatia, while Serbia was in the fourth place. Slovenia was first when it comes to total outflow of foreign investments among chosen countries. Other countries: Albania, Bosnia and Herzegovina, Montenegro and Macedonia attracted the insignificant amount of foreign direct investments. In 2006 just prior to the onset of the world economic and financial crisis, the FDI reached their peak. The countries of Central and Eastern Europe attracted significantly more FDI than the countries of Southeastern Europe. 
In literature there are a large number of empirical studies dealing with the analysis of the factors influencing the process of attracting capital from foreign investors. One of the most influential models in literature used as an assessment for choosing an entry mode to a certain foreign market is undoubtedly Dunning's "eclectic paradigm" or these called OLI-model (Dunning, 2001). The OLI model consists of three groups of factors. The "O" factor stands for ownership advantages, the "L" factor stands for locational advantages, and the "I" factor stands for internalization advantages. This model explains that if a company owns rare resources and competency enabling it to achieve competitive advantage, then it would be best to use a model of full ownership as internalization model, since it provides the best opportunity to exploit the rare resources it possesses (Stoian \& Filippaios, 2008). Contemporary literature on foreign direct investment expands the OLI model, especially the part that refers to specific assets or resources and to quasi-internationalization, in other words, internationalization through non-ownership organizational forms networks and alliances (Scott-Kennel \& Enderwick, 2004).

There is no dilemma in literature regarding numerous determinants affecting the process of attracting foreign direct investment but on the other hand, there is a great deal of disagreement on how significant the impact of chosen determinants actually is (Wei, Liu, Parker, \& Vaidya, 1999). There are also opposing opinions on whether economic growth has an impact on FDI, or the FDI have an impact on the economic growth (Pritchett, 2000), or it is simply the matter of cause-effect relationship. Thus, researching thirteen countries of Central and Eastern Europe, in the period from 1989 to 2006, when foreign direct investment recorded a continuous upward trend, and therefore confirmed the substantial positive effect on the economic growth, Neuhaus (2006) confirmed that countries with a high inflow of FDI had high growth rates as well. In the post-crisis period, foreign direct investment has a large role in dynamics of economic growth and strengthening of export competitiveness in Serbia (Radukić \& Ranđelović, 2014).

Earlier researches focused mainly on entry of western developed companies into markets of developing countries in Central and Eastern Europe, using OLI variables (ownership, location and transaction costs) as their starting point (Erramilli \& Rao, 1990; Agarwal, S. 1994; Aulakh \& Kotabe, 1997; Meyer, Estrin, Bhaumik \& Peng, 2009). According to (Meyer et al, 2009) in the initial years of transition, in the countries of Central and Eastern Europe, privatization was performed in form of partial acquisition. It can be said that the privatization was done by the principal of partial ownership of a state-owned company, where the state retained part of the ownership since the government did not allow total acquisition of stateowned companies. In their empirical study about entry modes of developed western countries into developing countries of Eastern and Central Europe, 
Bevan \& Estrin (2004) arrived at a conclusion that the very announcement of a country's accession to the European Union increases its attractiveness, leading to an increase in foreign direct investment i.e. models of full ownership. Authors further claim that workforce costs are a dominant factor in choosing a country, in other words, they follow efficiency seeking strategy. Dunning (2001) claims that building an infrastructure represents the most important factor in creating competitive advantage of a country and region especially in European countries in transition. Derado (2013) dealt with studying determinants that impact the attraction of the foreign capital by studying bilateral flows between pairs of Eastern European countries in order to determine whether Croatia used all its potential to attract foreign investment.

The structure of research is as follows. After the introduction, a detailed literature is manifested by similar studies that have explored the role and importance of foreign direct investment and relation to market size, competitiveness and employment in the world. The paper analyzes the next determinants: gross domestic product per capita, gross domestic product, share of industry in GDP and share of employment rate in total population.

The third segment shows macroeconomic framework in selected countries of South East Europe: Albania, Bosnia and Herzegovina, Bulgaria, Macedonia, Romania and Serbia from 2000 to 2012. After that, the methodology includes panel model creation with aim to identify the impact of macroeconomic factors on foreign direct investment. Also, the results reflect which factors are essential for foreign direct investment in selected countries. Finally, the last segment summarizes the conclusions with emphasis on future research.

\section{LITERATURE REVIEW}

There are numerous determinants that are significant in determining of foreign direct investment inflows. The most common determinants in empirical research are market size, market growth rate, market openness, foreign exchange rate, inflation rate, employment and labor productivity, as well as infrastructure and industry growth (Martinez-Zarzoso et al, (2004), Stefanović (2008), Satomi et al, (2007), Pelinescu \& Radulescu, (2009), Ranđelović-Petrović, Milić-Janković \& Kostadinović (2017), Aseidu (2002), Ang \& Michailov (2008), Villaverde \& Maza (2012), Marjanović \& Marjanović (2014), Bevan \& Estrin (2004), Campos and Kinoshita (2003), Kudina and Jakubiak (2008), Resmini (2000), Shukurov (2016), Kok \& Ersoy (2009), Aqeel \& Nishat (2004), Sasi \& Hristos (2015), Demirhan \& Masca (2008), Brouthers and Brouthers (2000), Mudambi \& Mudambi (2002), Bevan, Estrin \& Meyer (2004), Rodriguez \& Pallas (2008), Thomas \& Grosse (2001), Sun, Wilsonm\&Yu (2002), Artige \& Nicolini (2005), Charkrabarti (2001), Nasir (2016)). 
The majority of studies tested the hypothesis of significant correlation between market size and foreign direct investment (Brouthers and Brouthers (2000), Mudambi \& Mudambi (2002), Bevan \& Estrin (2004), Bevan, Estrin \& Meyer (2004), Rodriguez \& Pallas (2008), Thomas \& Grosse (2001), Aseidu (2002), Sun, Wilson, \& Yu (2002), Artige \& Nicolini (2005), Charkrabarti (2001), Nasir (2016)). Artige \& Nicolini (2005) emphasize that market size as measured by GDP or GDP per capita is the most robust FDI determinant in econometric analysis. Charkrabarti (2001) asserts that the market-size hypothesis supports that a large market is necessary for efficient resources utilization of and exploitation of economies of scale.

Martinez-Zarzoso et al, (2003) confirmed that a higher income in some country attracts the foreign investor interest to invest in that country. Likewise, author Stefanović (2008) pointed out that high growth rate of GDP per capita have positive impact on foreign direct investment inflows.

Also, a large number of papers researched the impact of GDP growth rate on foreign direct investment inflows (Ranđelović-Petrović, Milić-Janković \& Kostadinović (2017), Aseidu (2002), Somlev \& Hoshino (2005), Ang \& Michailov (2008)).

The authors Ranđelović-Petrović, Milić-Janković \& Kostadinović (2017) examined the relationship between market size and market growth rate on foreign direct investment in selected Western Balkan countries and concluded that these variables have a significant and positive impact on foreign direct investment.

Based on 30 empirical research conducted in developing countries and transition countries, the authors (Hornberger et al, 2011. in RanđelovićPetrović, Milić-Janković \& Kostadinović, 2017) confirmed a significant and positive relationship between market size and market growth rate on foreign direct investment inflows.

Bevan \& Estrin (2004) researched the entry of developed western countries of EU into Eastern and Central European countries and results show the importance of market size to attract foreign direct investment.

Campos \& Kinoshita (2003) used panel data regression analysis to study 25 transition economies to study in the period from 1990 to 1998 . They concluded that market size has a significant impact on foreign direct investment. Also, Kudina and Jakubiak (2008) as well as Resmini (2000) investigated significant and positive impact of market size on foreign direct investment in transition countries.

Shukurov (2016) researched the determinants for attracting FDI in transition countries with a special emphasis to the countries of Commonwealth of Independent States (CIS) countries, from 1995 to 2010. The results concluded that due to higher risk in transition countries, the choice of FDI location always depends on FDI stock, market size, abundance in natural resources and fiscal imbalance and inflation. 
The author Aseidu (2002) studied economic factors in selecting an investment type for chosen countries of the African continent. Based on the research, it is concluded that the growth rate of GDP per has a positive impact on foreign direct investment. Ang \& Michailov (2008) studied determinants for attracting foreign direct investment in Malaysia in the period from 1960-2005. They arrived at the conclusion that the real GDP has a significant positive effect on the inflow of foreign direct investment, whereas GDP growth rate has a moderately positive effect on the inflow of foreign direct investment. The author Nasir (2016) also confirmed positive and significant impact market size on foreign direct investment in Malaysia.

Researching developing countries authors (Kok \& Ersoy (2009), Aqeel \& Nishat (2004), Sasi \& Hristos (2015), Demirhan \& Masca (2008)) confirmed significant and positive impact of market share on foreign direct investment.

In addition to market size (GDP per capita) and market growth rate (GDP growth) as the most tested variables in empirical research, the employment share in total production as well as industry share stand out as important determinants for attracting FDI (Marjanović \& Marjanović (2014), Vilaverde \& Maza (2012), Somlev \& Hoshino (2005)).

Likewise, the industry is a development driver for the economic sector, productivity and employment of the national economy (Marjanović \& Marjanović, 2014). More industry's share of gross domestic product represents an essential factor for attracting foreign investors. Authors Somlev \& Hoshino (2005) confirmed significant impact the industry share growth of GDP on foreign direct investment inflows. Villaverde \& Maza (2012) studied the impact of 16 determinants on attracting foreign direct investments (FDI) in the Spanish market. They divided the stated factors into four big groups: (a) economic potential, (b) workforce conditions, (c) market and (d) competitiveness. Their findings show that workforce conditions and competitiveness, among which factors are the employment rate and share of industry GDP in the total GDP, have significant impact on the attractiveness of FDI.

Based on previous literature review, it is created a conceptual framework for defining a research problem, which relates to the examination of factor's influence in external environment on the process of attracting foreign investment in the market of Southeastern European countries. 


\section{MACROECONOMIC FRAMEWORK IN THE SOUTHEASTERN EUROPEAN COUNTRIES}

In order to analyze the impact of macroeconomic factors on the foreign direct investment in selected countries: Albania, Bosnia and Herzegovina, Bulgaria, Macedonia, Romania and Serbia, it is necessary to show their trend during the observed period.

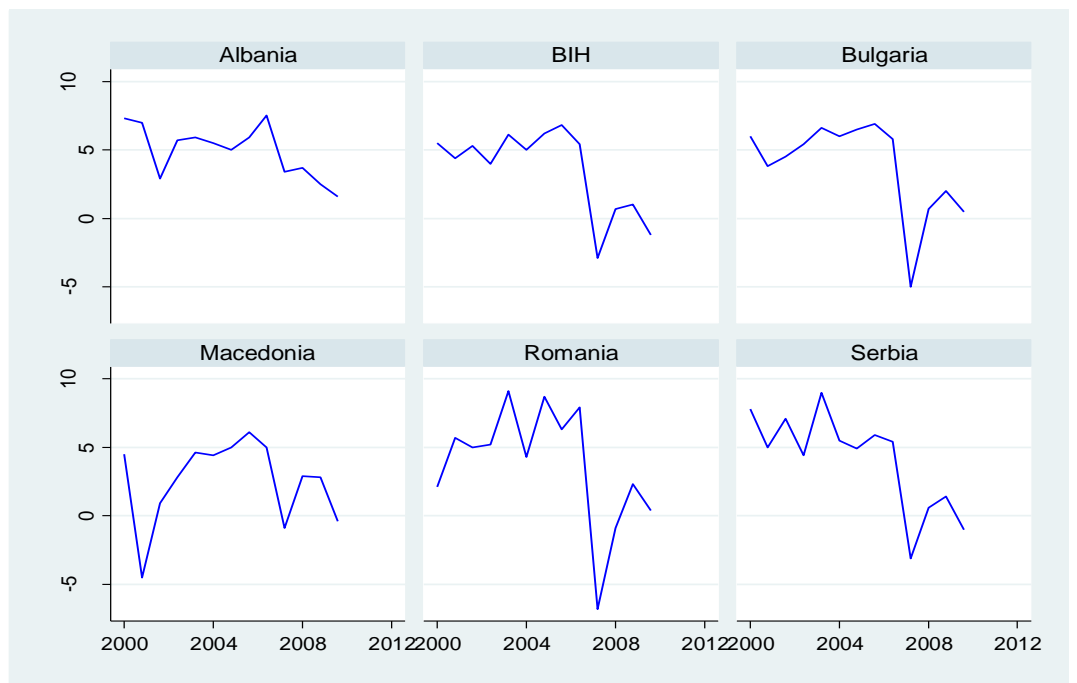

Figure 1 Gross domestic product in Southeastern European countries (\%) Source: Authors based on World Bank

Looking at GDP growth rate in selected countries, it can observe a similar trend during the period. Specifically, this applies particularly to the period before and after the crisis. In the pre-crisis period, the countries of Southeast Europe had an average GDP growth rate of 5.29\%, where Albania, Bulgaria and Romania had the highest growth rates. However, in 2009 there was an average decline of $2.55 \%$, whereas GDP declined for $5 \%$ and $6.8 \%$ in Bulgaria and Romania. Likewise, other countries recorded negative GDP growth rates, except Albania which had a positive GDP growth rate of $3.7 \%$. In analyzing the last three years, the average GDP rate stood at $0.18 \%$, which is far less than the level of the pre-crisis period. One of the reasons for this is the lower level of foreign direct investment in observed countries.

Based on Figure 2, Bulgaria and Romania are the leaders in terms of the level of foreign direct investment. As we can see, Romania had the highest level of 11450 million dollars in 2006 while Bulgaria attracted 13875 million dollars in next year. This is more even in other countries in the analyzed group for the observed period. For example, the maximum 
level of foreign direct investment is 4968 million dollars in Serbia while other countries attracted far less.

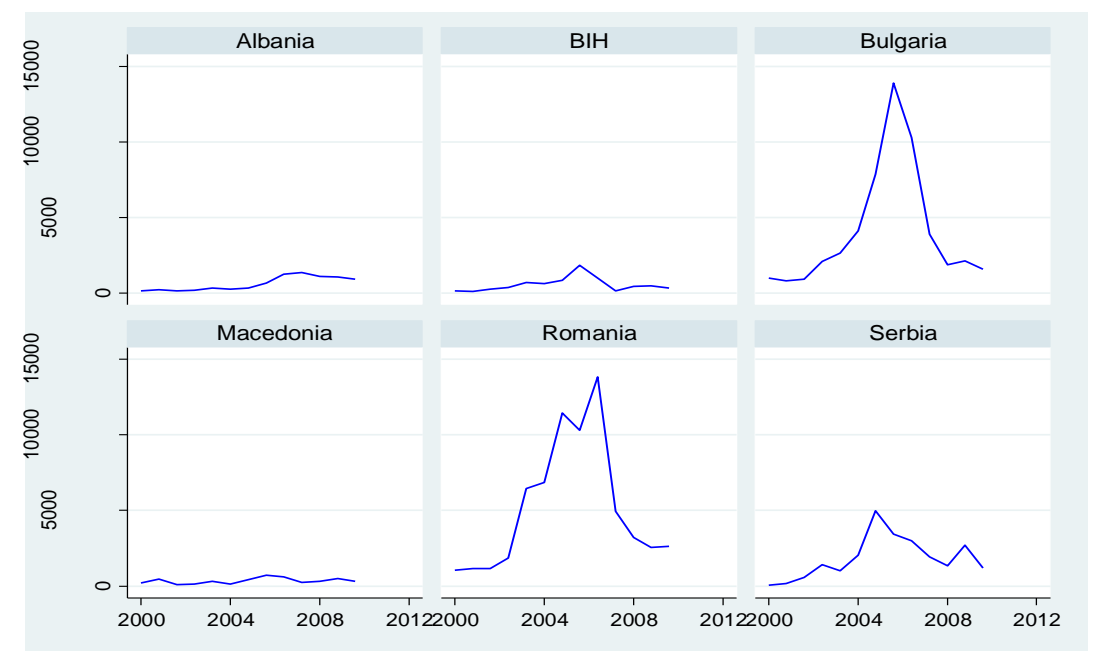

Figure 2 Foreign direct investments

in Southeastern European countries (millions \$)

Source: Authors based on World Bank

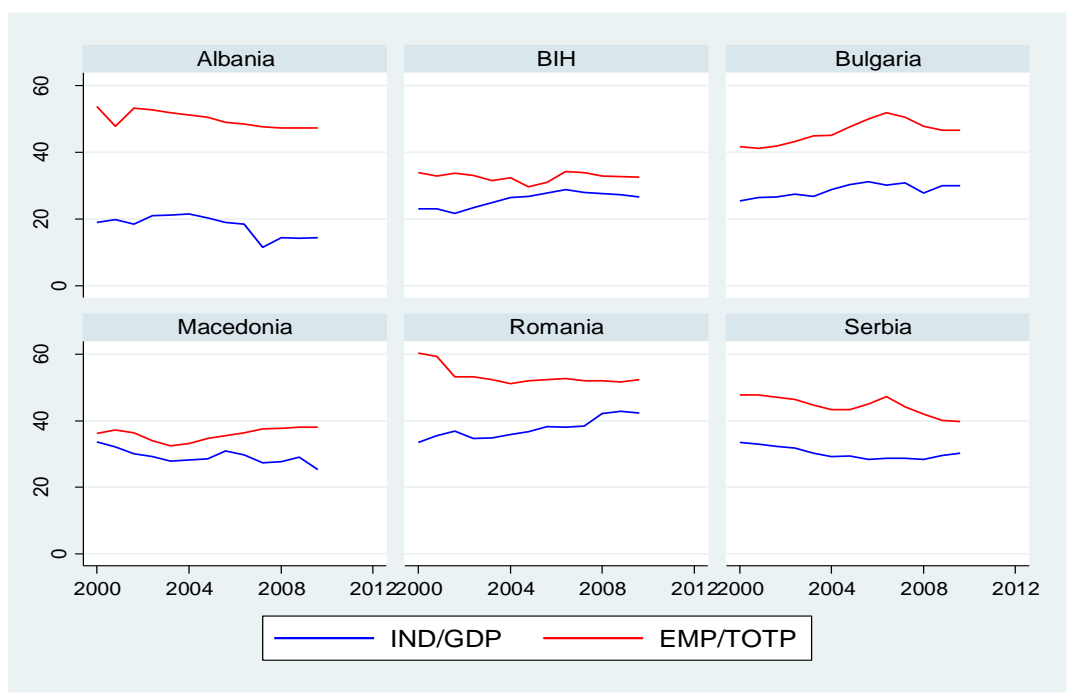

Figure 3 Competitiveness and employment in Southeastern European countries (\%)

Source: Authors based on World Bank 
Figure 3 represents the movement of competitiveness and employment in Southeastern European countries in the period 2000-2012. Looking at countries, industry's share is the highest in Romania about $40 \%$ compared to Albania where it is the lowest share, which can be attributed to the level of economic development in these countries. Looking at the trend, it is most reduced in Macedonia by $8.4 \%$, as well as Albania and Serbia, while there was an increase in other countries, especially in Romania with $8.9 \%$.

\section{DATA AND METHODOLOGY}

This segment is focused on the presentation data and examination effect of observed factors on foreign direct investment. The analysis includes panel model of six countries for the period 2000-2012, using a secondary database of World Bank. Selected countries are: Albania, Bosnia and Herzegovina, Bulgaria, Macedonia, Romania and Serbia.

Table 1 Review of variables

\begin{tabular}{|c|c|c|c|}
\hline Variable & Notation & Calculation & Source \\
\hline \multicolumn{4}{|l|}{ Dependent variable } \\
\hline Foreign direct investment & LOGFDI & millions $\$$ & World Bank \\
\hline \multicolumn{4}{|l|}{ Independent variables } \\
\hline Gross domestic product per capita & LOGGDPpc & millions $\$$ & World Bank \\
\hline Gross domestic product & GDPgrowth & $\%$ growth rate & World Bank \\
\hline Industry/Gross domestic product & IND/GDP & $\%$ share of GDP & World Bank \\
\hline Employment/Total population & EMP/TOTP & $\begin{array}{l}\% \text { of total } \\
\text { population }\end{array}$ & World Bank \\
\hline
\end{tabular}

Based on Brooks (2008) panel model is reflected as:

$Y_{i t}=\alpha+\beta x_{i t}+\mu_{i t}$

$Y_{i t}=$ foreign direct investment (LOGFDI)

$\alpha$ constant

$\beta x_{i t}=$ coefficients of the variables (LOGGDPpc, GDPgrowth, IND/GDP, EMP/TOTP)

$i=6$ countries

$t=2000-2012$

$\mu_{i t}=$ residual

The explanatory variables include:

Dependent variable:

LOGFDI - logarithmically value of foreign direct investment which is measured by millions \$; 
Market size factors:

LOGDGDPpc - logarithmically value of gross domestic product per capita which is measured by millions $\$$;

GDPgrowth - growth rate of gross domestic product measured by percentage; Competitiveness factors:

IND/GDP - measured by ratio of industry to gross domestic product by percentage;

Employment factors:

EMP/TOTP - measured by ratio of employees to total population by percentage;

\section{RESULTS}

In this part of the paper, the results are presented from a model which examines the impact of factors related to market size, competitiveness of the economy and employment in Southeastern European countries.

Table 2 Descriptive statistics

\begin{tabular}{lrcccc}
\hline Variable & Obs. & Mean & Std. Dev. & Min & Max \\
\hline LOGFDI & 78 & 6.830256 & 1.315752 & 3.95 & 9.54 \\
LOGGDPpc & 78 & 8.144487 & .2527442 & 7.64 & 8.7 \\
GDPgrowth & 78 & 3.785897 & 3.296071 & -6.8 & 9.1 \\
LOGGDP & 78 & 7.562051 & 1.070122 & 5.84 & 9.92 \\
IND/GDP & 78 & 28.26026 & 6.363221 & 11.56 & 42.78 \\
EMP/TOTP & 78 & 43.75256 & 7.770953 & 29.6 & 60.3 \\
\hline \multicolumn{7}{c}{ Source: Author's calculation based on STATA }
\end{tabular}

Table 2 reflects descriptive statistics of the explanatory variables for observed countries and includes 78 observations from 2000 to 2012. As it can see, EMP/TOTP and IND/GDP have the highest standard deviation, which is almost two or three times more compared to other variables.

Table 3 VIF test

\begin{tabular}{lcc}
\hline Variable & VIF & $1 / \mathrm{VIF}$ \\
\hline LOGGDPpc & 1.88 & 0.531435 \\
IND/GDP & 1.44 & 0.694895 \\
EMP/TOTP & 1.34 & 0.747059 \\
GDPgrowth & 1.15 & 0.873249 \\
Mean VIF & \multicolumn{2}{c}{1.45} \\
\hline
\end{tabular}

VIF test is used to determine the validity of the model and exclude potential multicollinearity between independent variables. Based on the value, it can be noted that there is no problem of multicollinearity, since the reference value is less than 4 . 
Table 4 Hausman test

\begin{tabular}{|c|c|c|}
\hline & Result & Conclusion \\
\hline $\begin{array}{l}\text { Random effect model } \\
\text { vs }\end{array}$ & $\operatorname{chi} 2(6)=(b-B){ }^{\prime}\left[\left(V_{-} b-V_{-} \_B\right)^{\wedge}(-1)\right](b-B)=7.68$ & $\begin{array}{c}\text { Fixed effect } \\
\text { model }\end{array}$ \\
\hline fixed effect model & Prob>chi ${ }^{2}=0.02$ & \\
\hline
\end{tabular}

In order to choose an adequate model, the Hausman test is included and as it can see, p-value (0.02) is less than 0.05 which means that fixed effect model is an appropriate model. Next table involves the impact of observed variables on foreign direct investment.

Table 5 Panel regression model

\begin{tabular}{|c|c|c|c|c|c|}
\hline \multicolumn{6}{|c|}{ Fixed-effect model } \\
\hline LOGFDI & Coef. & Std. Err. & $\mathrm{T}$ & $\mathrm{P}>(\mathrm{t})$ & $95 \%$ Conf. Interval \\
\hline \multicolumn{6}{|l|}{ Variable } \\
\hline LOGGDPpc & 4.266033 & .417753 & 10.21 & 0.000 & 3.432425 .099646 \\
\hline GDPgrowth & .1014672 & .0221671 & 4.58 & 0.000 & $\begin{array}{ll}.0572334 & .145701\end{array}$ \\
\hline IND/GDP & -.0466559 & .0286238 & -1.63 & 0.108 & -1037737. 0104619. \\
\hline EMP/TOTP & -.0042823 & .0282217 & -0.15 & 0.880 & 20520332. \\
\hline $\mathrm{C}$ & -2.547276 & .88532 & -2.88 & 0.004 & $\begin{array}{ll}4.282471 \quad .8120806 \\
\end{array}$ \\
\hline R-squared & & & & & 0.7337 \\
\hline Prob $>$ chi $^{2}$ & & & & & 0.0000 \\
\hline $\begin{array}{l}\text { Number of } \\
\text { observation }\end{array}$ & & & & & 78 \\
\hline
\end{tabular}

Table 5 represents panel regression model which measures the impact of four independent variables on foreign direct investment which is the dependent variable. Based on the result, it can see the positive impact of LOGGDPpc and GDPgrowth on foreign direct investment. On the other hand, IND/GDP and EMP/TOTP negatively affect on the observed variable. Likewise, it is important to emphasize LOGGDPpc and GDPgrowth have a significant impact on LOGFDI, while the effect of other variables is not statistically significant. The validation and reliability of this model are manifested in a high value of R-squared 0.7337 .

\section{CONCLUSION}

Based on the results in panel regression model, it can conclude that market size factors have a significant impact on foreign direct investment foreign in the countries of Southeast Europe. Gross domestic product per capita and gross domestic product growth rate have had a significant positive impact on foreign direct investment, which is in accordance with a number of 
empirical studies that have also confirmed a significant impact of market factors (Ranđelović-Petrović, Milić-Janković \& Kostadinović (2017), Aseidu (2002), Ang \& Michailov (2008), Campos and Kinoshita (2003), Kudina \& Jakubiak (2008), Nasir (2016), Resmini (2000), Kok \& Ersoy (2009), Aqeel \& Nishat (2004), Sasi \& Hristos (2015), Demirhan \& Masca (2008)). This market was attractive in the period from 2000 until the escalation of the global economic crisis due to an unused market potential which creates an opportunity for profitable investment because of the high growth rates of the market.

In mid-2008, Serbia reached only 72\% of GDP from 1989. Although, only three countries of Southeast Europe exceeded the level of GDP from 1989, where Albania reached in 2000, Macedonia in 2008, while Serbia was in the worst position. One of the less developed countries, Bosnia and Herzegovina achieved a 84\% level of GDP from 1989 (Uvalić, 2012, p. 205). In the period from 2001 to 2009, Romania, Albania, Bulgaria and Serbia had GDP growth rate over 5\%. After the escalation of the global economic crisis, there was a sharp decline of growth rate in all of Southeastern European countries, which is negatively affected by foreign direct investment. From 2011, investment activity has increased in this region. The industry's share of gross domestic product had affected the foreign direct investment inflows, but in a way that countries, which have smaller industry's share, attract more investment because of unused industrial potential, and thus the opportunities for greater growth of foreign direct investment. The results show that foreign direct investment significantly affected by market share Southeastern European countries.

The contribution is manifested in the fact that paper gives adequate information support to policy makers about the impact of different factors on foreign direct investment. This is particularly important for the countries of Southeastern Europe, where economic growth is largely dependent on the foreign direct investment inflows. Future research will be focused on expanding other factors such as the labour conditions, productivity and taxes which can have a significant impact on foreign direct investment. Similarly, a comparison with other EU countries can give certain answers in terms of the diversity of influence and importance of selected factors.

\section{REFERENCES}

Agarwal, S. (1994). Socio-cultural distance and the choice of Joint Ventures: A contingency perspective .Journal of International Marketing, 2(2), 63-80.

Agencija za strana ulaganja i promociju izvoza [Agency for Foreign Investments and Export Promotion] (2015). retrieved from http://siepa.gov.rs/sr/index/ sporazumi/cefta.html 
Ang, S. H., \& Michailova, S. (2008). Institutional Explanations of Cross-Alliance Modes: The Case of Emerging Economies Firms. Management International Review, 551-576.

Aqeel, A., \& Nishat M. (2004). The determinants of foreign direct investment in Pakistan. The Pakistan Development Review, 43(4), 651-664.

Artige, L., Nicolini, R. (2005). Evidence on the Determinants of Foreign Direct Investment: The Case of Three European Regions. http://pareto.uab.es/wp/ 2005/65505.pdf

Aseidu, E. (2002). On the Determinants on Foreign Direct Investment to Developing countries: Is Africa Different? World Development, 30(1), 107-119, DOI:10.1016/S0305-750X(01)00100-0

Aulakh, P. S., \& Kotabe, M. (1997). Antecedents and perfomance implications of channel integration in foreign markets. Journal of International Business Studies, 28(1), 145-175, DOI:10.1057/palgrave.jibs. 8490096

Bevan, A. A., \& Estrin, S. (2004). The determinants of foreign direct investment into European transition economies. Journal of Comparative Economics, 32, 775787, DOI:10.1016/j.jce2004.08.006

Bevan, A., Estrin, S., \& Meyer, K. (2004). Foreign investment location and institutional development in transition economies. International Business Review, 13(1), 43-64, DOI: 10.1016/j.ibusrev.2003.05.005

Brooks, C., (2008). Introductory Econometrics for Finance, Cambridge, University Press.

Brouthers, K. D. (2002). Institutional, cultural and transaction cost influences on entry mode choice and performance. Journal of International Business Studies, 33(2), 203-221, DOI:10.1057/palgrave.jibs.8491013

Brouthers, K. D., \& Brouthers, L. E. (2000). Acquisition or greenfield start-up? Institutional, cultural and transaction cost influences. Strategic Management Journal, 21(1) , 89-97, DOI:10.1002/(SICI)1097-0266(200001)

Campos, N. F., \& Kinoshita, Y. (2003). Why Does FDI Go Where it Goes? New Evidence from the Transition Economies. IMF Working Papers 03/228, International Monetary Fund.

Charkrabarti, A. (2001). The Determinants of Foreign Direct Investment: Sensitivity Analyses of Cross-Country Regressions. Kyklos (International Review for Social Sciences) 54(1), 89-114.

Demirhan, E., \& Masca, M. (2008). Determinants of foreign direct investment flows to developing coutries: A cross-sectional analysis. Prague Economic Papers, 4, 356-369.

Derado, D. (2013). Determinants of FDI in transition countries and estimation of the potential level of Croatian FDI. Financial Theory and Practice, 37(3), 227-258.

Dunning, J. H. (2001). Paradigm of International Production: Past, Present and Future. International Journal of the Economics of business, 8(2), 173-190.

Erramilli, M. K., \& Rao, C. P. (1990). Choice of foreign market entry modes by service firms: Role of market knowledge. Management International Review, $30(2), 135-150$.

Hornberger, K., Battat, J. \& Kusek, P. (2011). Attracting FDI: How Much Does Investment Climate Matter? The World Bank Group, Financial and Private Sector Development Vice Presidency, Note no. 327 in: Ranđelović, P. M, Milić, J. V. \& Kostadinović, I. (2017). Market size as a determinant of the foreign direct investment in flows in the Western Balkans countries.Facta Universitatis, Series: Economics and Organization, 14(2), 93 - 104.

Kok, R., \& Ersoy, A. B. (2009). Analyses of FDI determinants in developing countries. International Journal of Social Economics, 36(1/2), 105-123. 
Kudina, A., \& Jakubiak, M. (2008). The Motives and Impediments to FDI in the CIS. Global Forum on International Investment. www.oecd.org/investment/gfi-7.

Marjanović, V., \& Marjanović, M. (2014). Podsticanje razvoja industrije kao ključna determinanta strategije restrukturiranja privrede Republike Srbije. [Simulation of industrial development as the key determinant of the strategy of Serbia economic restructuring]. Teme, 38(4), 1425-1444.

Martinez-Zarzoso, \& Nowak-Lehmann, F.D. (2004). Economic and geographical distance: Explaining Mercosur Sectoral Exports to the EU. Open Economies Review, 15(3), 291-314.

Nasir, A. (2016). Market Size, Exchange Rate and Trade as a Determinant of FDI the Case of Malaysia. American Journal of Business and Society, 1(4), 227-232.

Neuhaus. M. (2006). The Impact of FDI on Economic Growth, Springer-Verlag Company.

Pelinescu, E., \& Radulescu, M. (2009). The Impact of Foreign Direct Investment on the Economic Growth and Countries' Export Potential. Romanian Journal of Economic Forecasting, 4, 153-169.

Pritchett, L. (2000). Understanding Patterns of Economic Growth: Searching for Hills among Plateaus, Mountains and Plains", World Bank Economic Review, UNCTAD Investment Brief, No.2 2008

Radukić, S., \& Ranđelović, P. M. (2014). Strane direktne investicije kao imperativ unapređenja konkurentnosti srpske privrede u postkriznom periodu. [Foreign direct investment as an imperative for improving the competitiveness of Serbia economy in the post-crisis period]. Teme, 38(2), 507-526.

Ranđelović, P. M, Milić, J. V. \& Kostadinović, I. (2017). Market size as a determinant of the foreign direct investment in flows in the Western Balkans countries. Facta Universitatis, Series: Economics and Organization, 14(2), 93 - 104.

Resmini, L. (2000). The determinants of foreign direct investment in the CEECs: new evidence from sectoral pattern. Economics of transition, 8(3), 665-68.

Rodriguez, X. A., \& Pallas, J. (2008). Determinants of foreign direct investment in Spain. Applied Economics, 40(19), 2443-2450, DOI:10.1080/00036840701367606

Sasi, I.,\& Hristos, D. (2015). Does Growth Attract FDI? Economics Discussion Papers, No 2015-18, Kiel Institute for the World Economy. http://www.economics ejournal.org/economics/discussionpapers/2015-18

Satomi, K., David, S., \& Nigel, D. (2007). Macro determinants of FDI inflows to Japan: An analysis of source country characteristic. Aston University

Scott-Kennel, J., \& Enderwick, P. (2004). Inter-firm Alliance and Network Relationships and the Eclectic Paradigm of International Production: An Exploratory Analysis of Quasi-internalisation at the Subsidiary Level. International Business Review, 13(4), 425-445, DOI:10.1016/j.ibusrev.2004.03.004

Shukurov, S. (2016). Determinants of FDI in Transition Economies: The case of CIS Countries. Journal of International and Global Economic Studies, 9(1), 75-94.

Somlev, I. P., \& Hoshino, Y. (2005). Influence of location factors on establishment and ownership of foreign investments: The case of the Japanese manufacturing firms in Europe. International Business Review 14, 577-598.

Stefanović, S. (2008). Analitical framework of FDI determinants: Implementation of the OLI Model. Facta Uneversitatis: Economics and Organization, 5(3), 239-249.

Stoian, C., \& Filippaios, F. (2008). Dunning's eclectic paradigm: A holistic, yet context spcecific framework for analysing the determinants of outward FDI Evidence from international Greek investments. International Business Review, 17(3), 349-367, DOI:10.1016/j.ibusrev.2007.12.005

Sun, Q., Wilson, T., \& Yu, Q. (2002). Determinants of foreign direct investment across China. Journal of International Money and Finance, 21(1), 79-113, DOI:10.1016/S0261-5606(01)00032-8 
Tarzi, S. (2005). Foreign Direct Investment into Developing Countries: Impact of Location and Government Policy" . The Journal of Social, Political and Economic Studies, 30(4), 497-516.

Thomas, D. E., \& Grosse, R. (2001). Country-of-origin determinants of foreign direct investment in an emerging market: the case of Mexico. Journal of International Management, 7(1), 59-79, DOI:10.1016/S1075-4253(00)00040-5

Uvalić, M. (2012). Tranzicija u Srbiji - ka boljoj budućnosti. Beograd.

Villaverde, J., \& Maza, A. (2012). Foreign direct investment in Spain: Regional distribution and determinants. International Business Review, 21(4), 722-733, DOI:10.1016/j.ibusrev.2011.08.004

Wei, Y., Liu, X., Parker, D., \& Vaidya, K. (1999.). The regional distribution of foreign direct investment in China. Regional Studies, 33(9), 857-867, DOI:10.1080/ 00343409950075498

World Bank (2015), retrieved from http://www.worldbank.org/en/country/

\section{УТИЦАЈ МАКРОЕКОНОМСКИХ ФАКТОРА НА СТРАНЕ ДИРЕКТНЕ ИНВЕСТИЦИЈЕ У ОДАБРАНИМ ЗЕМЉАМА ЈУГОИСТОЧНЕ ЕВРОПЕ}

Јелена Андрашић, Вера Мировић, Бранимир Калаш

Универзитет у Новом Саду, Економски факултет у Суботици, Суботица, Србија

\section{Резиме}

У условима глобализације стране директне инвестиције представљају један од најзначајнијих развојних ресурса савремене светске привреде и један од важнијих фактора развоја националних економија. То се нарочито односи на земље југоисточне Европе које су прешле са планског концепта привреде на либералнотржишни концепт. Сходно томе, интерес земаља огледа се у привлачењу страних директних инвестиција будући да оне доприносе привредном расту, модернизовању привредне структуре, расту производње и конкурентности, као и извозне оријентације и порасту запослености. У раду су испитивани фактори који утичу на прилив страних директних инвестиција у одабраним земљама југоисточне Европе: Албанија, Босна и Херцеговина, Бугарска, Македонија, Румунија и Србија, у периоду од 2000. до 2012. године. Анализирани фактори подељени су у неколико група: а) величина тржишта посматрана је кроз логаритмовану вредност бруто домаћег производа по глави становника и стопу раста; б) конкурентност привреде анализирана је кроз учешће индустрије у бруто домаћем производу и в) запосленост је посматрана кроз учешће запослених у укупној популацији. Коришћењем одговарајућих тестова, представљен је модел који одражава значајност утицаја одабраних фактора. Истраживање је показало да величина тржишта позитивно утиче на прилив страних директних инвестија, док, с друге стране, учешће индустрије у БДП-у и запосленост имају негативан утицај на стране директне инвестиције. Исто тако, утицај датих варијабли значајан је само у погледу ефеката величине тржишта на прилив страних директних инвестиција у посматраним земљама југоисточне Европе. 